\title{
Investigating the Effective Factors on the Occurrence of Smuggled Goods in Iran
}

\author{
Alireza Aghazadeh ${ }^{1}$, Mohammadali Ardebili ${ }^{1}$, Mohammad Ashouri ${ }^{1} \&$ Mohammadali Mahdavisabet $^{1}$ \\ ${ }^{1}$ Department of Criminal Law and Criminology, Faculty of Law and Politics, Science and Research Branch, \\ Islamic Azad University, Tehran, Iran \\ Correspondence: Mohammadali Ardebili, Department of Criminal Law and Criminology, Faculty of Law and \\ Politics, Science and Research Branch, Islamic Azad University, Tehran, Iran. E-mail: isisarvak@gmail.com
}

Received: July 2, $2016 \quad$ Accepted: September 26, $2016 \quad$ Online Published: December 9, 2016

doi:10.5539/jpl.v10n5p17 URL: https://doi.org/10.5539/jpl.v10n5p17

\begin{abstract}
This study aims to examine the economic and social factors affecting emergence of smuggling goods and government's approach toward it. The crime of smuggling goods is one of the most important economic crime factors causing irreparable damage to the country's economic system and also is seriously threatened social and cultural principles and values that govern the society. Other studies have determined the emergence of smuggling goods due to multiple factors of economic, social, and cultural, which are surveyed in this research as the most important effective factors on occurrence of smuggling goods. The aim of this research is to focus on economic and cultural factors existing in this field. In this study, we will conclude how cultural factors and consumption patterns cause the phenomenon of smuggled goods.
\end{abstract}

Keywords: factors affecting smuggling goods, economy affected by smuggling goods, import and export of smuggled goods

\section{Introduction}

Smuggling of goods is part of the country economy aiming to take advantage from the illegal trade agents. Iranian custom statistics of seizures of smuggled goods indicate the increasing number of trafficking cases, in recent years. According to the statistics, the total number of cases has increased from 28829 cases in 1995 to 77,829 counts in 2003. Due to the hidden nature of trafficking itself, the real statistics of smuggling goods is not recorded in official statistics and subsequently, it would cause being the hidden part of the country's economic performance, this fact in practice can encounter with the difficulties function of allocation and distributive policies of government. However, with the knowledge of the trafficking process or its volume with using of the strategies, it can be lead to, into the formal economic activities recorded in the national accounts other than activities in the informal economy simultaneously (Bahrami and Ghasemi, 2007). It is important to know the size of smuggling in Iran inevitability. This article tries to answer the following questions. 1) How the smuggling procedure has been in Iran during the last three decades? 2) What are the factors that affect the size of smuggling? 3) What are the consequences of changes in the volume of traffic? 4) What ways is suggested to reduce the size of trafficking? Methods of survey in this study is based on literature related to hidden variables as a special case of Model 1, where the use of indicators and general multiple causes (MIMIC) is linear structural relations (Lisrel), the size of smuggling in Iran is estimated. 2 One of the main drawbacks to empirical studies in the literature of hidden variables is lack of theoretical basis consistent with the planed modeling of Lisrel model, 1. Multiple- Indicators Multiple-Causes 2 .Linear Structural Relationships www.SID.ir Archive of SID Economic Bulletin 46, in this economic research, the study for the first time at the level of foreign and domestic studies, not only this weakness was offset and introduce a theoretical model for trafficking, the empirical modeling is done consistent with it for estimating the size of the smuggling in a time series.

\subsection{Economic Factors}

\subsubsection{The Relative Desirability of Foreign Goods}

The desirability of foreign goods is one of the main factors of demand for these products in the domestic market and hence the factors of trafficking with identification of taste and demand of domestic consumers, and type and extent of available demand with the aim of gaining more profit from illegal trade de facto carry out supplying 
goods from the unofficial route (Sheikh, 1974). There are several factors of interest for foreign goods consumption that the most important of them can be named as follows:

\subsubsection{Beauty and Innovation in Design and Color of Products}

Because of the being diversity and being interested to beauty is including of the inherent characteristics in every human, hence big companies manufacturing consumer products in order to attract customers and selling more products and ultimately gaining more earn, have considered innovation and invention in the design of its industrial as the main core of its activities and constantly try to create diversity and attractiveness according to consumer's tastes and nature in its industrial production. And this despite the fact that domestic production of country in terms of diversity and attractiveness and customer-friendly don't have ability to compete with foreign trafficking products and does not provide the available demand for consumption of these kind of goods and of course the smuggling of foreign goods is placed in the basket of consumer goods of compatriots (Gassin, 1992).

\subsubsection{Desirability of Quality and Quantity of Foreign Goods}

Desirability of commodity is among the features of a product both in terms of quality and quantity and the price that make the product to be requested and has been sold, Product quality is important for all consumers So that with the same conditions of access and price often consumers prefer to buy quality products rather than inferior and undesirable goods and to the assumption in accordance with the popular saying that "we do not have much money to buy inexpensive goods (cheap))" (Bakhshinejad, 2001). Buy quality goods, even if they have high prices. Lack of after-sales service or guarantee of related to product quality; provide grounds caused losses to consumers.

\subsubsection{Unreasonable Tariffs for Import and Export of Goods}

In the literature of international trade, tariff to be remembered is the second best policy. Custom tariffs can be a kind of tax on imports (and often exports) that cause increasing in the prices of goods for consumers and the domestic producers. Economists believe that the enacting of tariffs from the direction of undeveloped countries cause increasing prices of imported goods, reducing domestic consumption, increase domestic inefficient production, reduce imports, generate revenue for the government, redistribution of income and create inefficiency (which are known to support costs) (Lovely and Nelson, 1995; Seif, 1999). However, developing countries to implement of support policies have specific reasons, such as: protection of infant industries, the problem of external balance of payments, government income and the like this. Basically, trade restrictions and adopted support procedures resulted from the government's desire for change in the volume and pattern of trade that is determined by free competition. Tools used for protection of domestic products of developing and developed countries are very diverse. In general, these tools divided into two parts of precious and non-precious. Precious tools are including tariff policy, foreign policy and manufactured subsidies (Fausti, 1991). Non-precious tools include import licenses (permits), quotas, import restrictions, administrative barriers and technical barriers exception of tariffs of other protectionist instruments is part of tariff barriers. In our country, thus tariffs are applied on imported goods. Applied tariff rates in our country is illogical and more than other countries in the region and this is one of the main reasons for the being favorable background of smuggling goods into the country. Because the price of imported goods rises inefficiently from legal bases with obtaining further tariff and importers to reduce these costs and being earning more profit of smuggling turn to illicit crime. In our country in addition to obtaining the tariffs, other amounts with different titles (like- tariffs) are taken from imports. These amounts include all additional costs and other import taxes, is not the title customs duties and commercial benefit. Raising the rate of custom protections in the country and existence of smuggled goods on a massive scale indicates that the amount of this support should be amended to reduce the incentive for smuggling of goods. Obviously, if artificial barriers (tariff and non-tariff) be in the normal course of business, the illegal trade of smuggling goods is exacerbated and this case cause smuggling. Research suggests that there is direct link between trade policy and informal market. Rahmdel (2007) in his study entitled "smuggling of goods and currency in the Iranian criminal law" examined the effect of the extent of customs protection and its links with smuggling of goods and the results of his studies show that commodity imports with lower tariff rates will lead to reduce import and lower smuggling of goods. Based on the results of this research, tariffs should not be over 20 percent otherwise it would lead to underground activities. On the other hand, unconditional release of the goods import into the country, cause irreparable damages to production and economy of the country .In May 2006, according to suggestion of the Minister of Industry and Mines of country (time) increased import tariffs for mobile phone. Because of support of domestic products and create incentives for investors, import tariffs of mobile phones increased from $4 \%$ to $60 \%$ so artisans can maximum use from requirement of phone market that was about 10 million units alone in last year. Import tariff policy of the government in import of mobile phone 
with reducing import of formal borders lead to economic boom and profit in smuggling. Therefore it can be seen in action that government protection policies of some local products not only have not a positive impact on domestic products but also has increased the smuggling of these goods. Therefore, reduction of custom tariffs to prevent of trafficking is of solutions that Enrico Ferri deals with to it in the discussion of "the punishment currencies". He advised the government to prevent of the smuggling of goods do not need to use punishment or repressed leverage. Reduction of government revenue, the importer will lead to the adoption of the law rather than take the risk. "Trafficking, turned into resistance against severe and terrible punishments like amputation of the hand, and death for centuries and in our time, prison and shot the offending of different Customs officers also failed to prevent the smuggling of goods. The reduction of customs rates in France, traffic declined in that country. Adam Smith (1790-1723) was right in his book "The Wealth of Nations", to declare: legislation that stimulates People to trafficking and then due to commitment of trafficking punish them to justice and cusses factor of stimulation be stronger and intensification of punishment, is a law, contrary to all the principles of legal justice. "So if custom tariffs reduce and the importer of goods feels that there is a common interest despite of payment of tariff costs, he will continue to pay the customs fees rather than acceptation of smuggling risk and with paying the custom fees, deal with to the import of goods (Bhagwati and Hansen, 1973).

\subsubsection{Trading Rules}

Trade and customs laws alone are not effective in the incidence of smuggling and not to improvement and revision of the structure of trade rules and regulations, Trafficking can be eradicated forever. Trafficking resulted from many factors that contribute to the commercial and customs laws. But some of the contributions should not be underestimated in terms of impact although in terms of the number of cases seem less than other factors, Because business and customs laws is effective in outbreak, escalation or reduction of smuggling (Johnson, 1974). These factors include:

1) The structure of the rules (trade, customs) has the following problems:

-Being no clear of law

- Changing the rules

-instability

-Having no Conform with present reality

- Not connecting the rules to the needs of society, Volatility or instability,

- Providing field of monopolies and loss of healthy competition, in business

- being inaccurate and incomprehensive rules,

- Irrational tendencies laws to protect domestic production regardless of quality, price, and...

- Interfering with other laws

-Frequent changes in laws

- The number of rules

2) Statutory prohibition

3) Regulatory restrictions

4) There are numerous legal requirements, including establishment of import or export licenses, requirements related to the use of internal transportation in import, insurance of imported goods to Iranian insurer, duty payment before the entrance that underlying cost and being expensive of the price of imported goods, Financial standards, health and safety considerations of the product, process order goods at the Ministry of Commerce and Bank, foreign exchange obligations, etc.

5) Tariff barriers and para-tariffs, including diversity, and numbers of tariffs as well as being unreasonable,

6) The complexity of the calculations to import or export duties paid, 7) Excise on imports,

8) Direct taxes from the importer, domestic producer, domestic products, as well as production or sales duties.

\subsubsection{Giving Subsidies to Some Domestic Goods}

Subsidy refers to a variety of government transfer payments in order to raise consumer welfare. In other words subsidizing is part of the price of goods or services in order to increase purchasing power of consumer or increase selling power of producer. In order to make economic and social justice and benefiting all segments of society, from a minimum of amenities and livelihood feasibilities, the government pays subsidies for some goods 
and for subsidizing usually three aims, which include ; optimum allocation of resources, economic stability and fair income distribution. Allocation of subsidies on basic commodities will lead to differences between domestic and international prices (Norton, 1988). The difference between the prices is incentive to create demand and smuggling of goods from countries with lower domestic prices than world prices for another country. Domestic prices of some commodities, including energy carriers such as oil, gasoline and other commodities such as flour, medicines because of the government pays subsidies to them, in domestic markets of Iran is far less than the market of neighboring countries (Firuzjaee, 2003). The difference between the prices is raised exit of such goods by traffickers and even ordinary people for the supply of their foreign currency needs in abroad. So as long as the subsidies payments are not targeted in the country and the differences in price caused by the subsidies remain in place, traffic will be profitable (ibid). The present Subsidy system in the economy of Iran has been one of the affecting factors on trafficking of the exported goods. Because subsidies payment on some basic goods, cause differences of prices of these goods in the domestic market to the foreign markets of neighboring countries on the one hand and the creation of informal market of buying and selling of such goods in the actual price on the other hand. With consideration of difference in price from subsidies on some goods, gross profit from trafficking also increased in these goods, So long as the subsidies allocation for goods not to be targeted and this difference of price from subsidizing remain in place, trafficking also will be profitable, and full and proper implementation of targeted subsidies law of 2010 came into force, can be effective in reducing the illicit of export of domestic goods.

\subsubsection{Official Paperwork and Lengthy Process of Formal Import and Export}

According to regulations of import and export, import of goods and customs clearance some of imported goods subject to the authorization of some ministries and agencies, including, Ministry of Industry, Mine and Trade, Agriculture, Health and Medical Education, ICT, oil, Culture, Defence and Armed Forces Logistics, Science, Research and Technology, Roads and Urban Development, Environmental Protection Agency, Atomic Energy Agency, the country's forests, the General Directorate of Civil Aviation, the Central Bank and ... As well as several other ministries and organizations under the terms of export and import laws, export certificates related to allow clearance of imported goods or exported goods, Which can be noted :Standard Institute, Ministry of Agriculture, Ministry of Health and Medical Education, Ministry of Islamic Culture, Ministry of Communications and Information Technology, Ministry of Defense and Armed Forces Logistics, Oil Ministry, Central Bank and other institutions. Official paperwork for export and import of goods also result in a long and costly legal procedures and stagnating of exporter and importer capital as well as the deterioration of their goods. For this reason, some traders are forced to ignore the rules and $t$ export or import their goods through illegal route. The result is the widespread smuggling of goods. Being prolong of trade and customs provisions and procedures is the effect of the following factors: Not Transparency of decisions, instructions and regulations related to a commercial, banking, tax, health, safety, and financial performance to be delivered to Customs.

Being allowed to apply different rates to each other creates problems and prolong customs formalities between the owners of goods and custom that.

The multiplicity of import licenses the multiplicity of certification organization.

The complexity, scope and long duration of the administrative process of official imports is of reasons of trafficking increase in the country and has caused some importers apply to trafficking imports, to acceleration the importation. In fact, it seems that the group did not engage on contraband imports for tax evasion on import, but the length of the import process has affected on decision.

\subsection{Social and Cultural Factors}

\subsubsection{Unemployment, Underdevelopment and Deprivation Residents of Border Areas}

Reduce of the rate of formal employment is both justifying and reason of increase the employment rate in the informal economy and smuggled goods. Increase of labor supply and decrease of demand for labor in the formal sector could increase employment in the informal sector. Therefore, the reduction of employment rate in the formal economy is justifying of trafficking increase, particularly in border areas. Unemployment in addition to cut income and increase of the unemployed has social consequences, and it can be increasing factor or origin of great social corruptions and in the most optimistic state could lead to the development of mediation and trafficking. In other words it can be said that the decline in employment in the formal economy, increase the rate of employment in the informal economy and smuggling. Therefore, unemployment rate in the formal economy has direct connection with increase of smuggled goods. 11 
According to the magazine of "tomorrow industry" in Hormozgan province, 200 thousand people named: "paratroopers" are engaged in the smuggling of goods.

The unemployment rate in the country not only in the past decade was significantly high, but it has increase procedure. Lack of productive jobs in the border regions has caused that young people become hired workers to earn more income for smuggling networks because they don't have enough capital themselves, to work. While the average unemployment rate was declared 18 percent in 2007, the provinces of Ardebil, Bushehr, Khuzestan, Sistan and Baluchestan, Kordestan, Kermanshah, Golestan, Gilan, and Hormozgan are with unemployment rates higher than the average of country. However, rural areas of the borders have higher rate of unemployment.

Check the status of border provinces shows that, despite of actions taken in order to deprivation over the past two decades; these provinces are still heavily in the economic and cultural deprivation. This means that on the one hand due to weather patterns, soil types and lack of capital possibilities, there is no basis for employment in agriculture and on the other hand for various reasons, industrial activities in these areas is lagging (Cheraghi and Heidari, 2016). Anti-smuggling law passed in 2014 to strengthen of border livelihood and development of economic activities of border areas and eventually reduce the rate of smuggling in the border areas of the country the Ministry of country (Interior) is mandated to cooperate with the headquarters (central staff) of the Anti-smuggling, and prepare the bill currency of development and sustainable security of the border areas to and submit for approval to the Council of Ministers, that Until the formulation of this thesis, action has not been taken in this regard (ibid).

\subsubsection{Changing Consumption Patterns of the Society toward Foreign Luxury Goods}

Extension of telecommunications, being satellites TV, foreign travel, a variety of advertising of foreign goods in stores and locations across the country, seeing the use of this product to acquaintances, quick access to information related to the present of new products and their quality and like this, have cause to consumers receive update information in the level of world. Now, according to those in respect of quality, price and variety of foreign goods mentioned, this factor is increased demand for foreign goods. In the field of goods consumption has been considered three approaches theoretically: The first approach, assumes a passive consumer and consumption assumes a kind of manipulation on the behalf of power. In the second approach, look to consumption is assumed as a medium for communication. Consumption in the view is a kind of rivalry, competition and communication. And the third approach, its consumption is assumed to be a secondary production. Consumer with consumption behavior, starts innovations as a result of, oh his it will be brought down power. Factors such as increased income, advertising, quality weakness of internal productions and other factors, has caused the consumption pattern of society changes toward foreign luxury and consumed goods in recent years (Fausti, 1991). And these despite the fact that major of the goods have not the possibility of business entry into the country. More importantly, is that the consumption types of luxury goods and foreign consumed goods have become an almost stable consumption patterns for households in high-income and part of middle-income families. This pattern of consumption has shown its conflict as undermine the culture of consumption pattern of Iranian goods. High demand for consumption of foreign goods and substantial income that through obtained illegal importers and sellers of goods smuggled, have increased significantly scope and volume of the arrival of the goods. Unfortunately, consumer culture to motivate people to consume foreign goods has caused even some domestic manufacturers to present their products with abroad.

\subsubsection{Conversion of Smuggling into the Local Culture}

Social - cultural components in formation of trafficking phenomenon linked mainly with social justice. Social justice is commitment to justice in the social relations and the elimination of discrimination between social groups, social classes, ethnic groups and races and between different regions. In fact, social justice is presence of equal opportunities for getting education and, skill of access to physical and financial capital through the appropriate markets. If there is damage in the area, form abnormal social phenomenon that one of the most important of them are the prevalence of smuggling and the loss of its social evil. Residents of border areas since ancient times have economic relations by the inhabitants of cross-border and always estimated level of transactions has been authorized by the government between them, but after the applying severe restrictions of trade and exchange controls and profitable smuggling of goods, the practice was more widespread among residents of border areas. After the cancellation of non-pecuniary penalties for shipments of less than a million dollar, contraband cargo shifted with worth of less than one million dollars and increased volume of illegal employment and a significant proportion of residents of border areas resorted to smuggling over the past years so opposition to it, is difficult. Smuggling has been affected of how to make and enforce rules in the community and more people due to the current situation, suppose trade laws are unfair and justify their violations in the field 
(Johnson, 1974). The lack of a legal ban on informal trade and smuggling on behalf of elders and religious scholars of Sunni in border areas has led to the employment of labor smuggling become as a way of promoting of income and employment of people convert to a subculture and social value and those who are active in the field by denying their violation of social norms and obligations without any concern and unscrupulous do smuggling and in most cases also benefit from the cultural support and popular support. Remarkably, even in terms of some Sunni scholars in the border areas in the seizure of smuggled goods into the country, police seized evidence and its buying and selling, is prohibited and the property must be returned to their original owners. Therefore, people of the some areas avoid of purchasing and consumption of such goods that sometimes are being sold through customs or respective departments (since seized).

\section{Conclusion}

Based on research into the affecting factors on the occurrence of trafficking of goods in Iran the following results were obtained:

1) One of the main causes of smuggling in border cities is poverty and unemployment due to the increase in labor supply and decrease of demand for labor in the formal sector is causing it.

2) Cultural issues and the desire of people to use of foreign products because of better quality make appeal to consumers.

3) According to regulations of import and export, import of good and customs clearance some of the imported goods are subject to catching license some of the various ministries and agencies that this long process has led to smuggling.

4) Unreasonable tariffs for import and export of goods are one of the factors that cause the economic issue and rationalizing this situation can help to improve smuggling problem.

\section{References}

Bahrami, M., \& Ghasemi, B. (2007). Smuggling pathology in Iran. Farabi Institute Publication, Tehran.

Bakhshinejad, M. (2001). Criminological survey of smuggling goods in Sistan and Baluchestan state. M.A. thesis criminal law and criminology, Tehran Central Branch, Islamic Azad University.

Bhagwati, I., \& Hansen, B. (1973). A theoretical analysis of smuggling. Quarterly Journal of Economic, 87(2), 172-187. https://doi.org/10.2307/1882182

Cheraghi, D., \& Heidari, K. (2016). Survey of effective factors of smuggling goods in Iran with emphasis subsidencis rule. Tarbiat Modares University.

Fausti, S. W. (1991). Smuggling and parallel markets for export. Department of Economics Staff Paper Series. P. 83.

Firuzjaee, M. (2003). Survey of effective factors on smuggled goods in Iran. Tadbire Eghtesad Research Institute, Tehran.

Gassin, R. (1992). La criminology. Dalloz-Sirey, coll.

Johnson, H. (1974). Notes on the economic theory of smuggling, Malayan Economic Review (1972). In J. Bhagwati ed. reprint on Illegal Transactions in International Trade, Amsterdam: North-Holland.

Lovely, M. E., \& Nelson, D. S. (1995). Smuggling and welfare in Ricardo-Viner economy. Journal of Economic Studies, 22(6), 26-45. https://doi.org/10.1108/01443589510099039

Norton, D. A. G. (1988). On the economic theory of smuggling. Economica, (55), 5-15. https://doi.org/10.2307/2554250

Rahmdel, M. (2007). Smuggling of goods and currency in the Iranian criminal law. Journal of Legal Research, $10,124-146$.

Seif, A. (1999). Smuggling goods in Iran. Islamic parliament of research center.

Sheikh, M. A. (1974). Smuggling production and welfare. Journal of International Economics, 4(4), 355-364. https://doi.org/10.1016/0022-1996(74)90016-6

Tenth united congress on the prevention of crime and treatment of offenders Vienna austral, 1997. 


\section{Copyrights}

Copyright for this article is retained by the author(s), with first publication rights granted to the journal.

This is an open-access article distributed under the terms and conditions of the Creative Commons Attribution license (http://creativecommons.org/licenses/by/4.0/). 